\title{
Heresy and Identity in Late Antiquity
}

\section{Ed. by Eduard Iricinschi and Holger Michael Zellentin}

[Häresie und Identität in der Spätantike.]

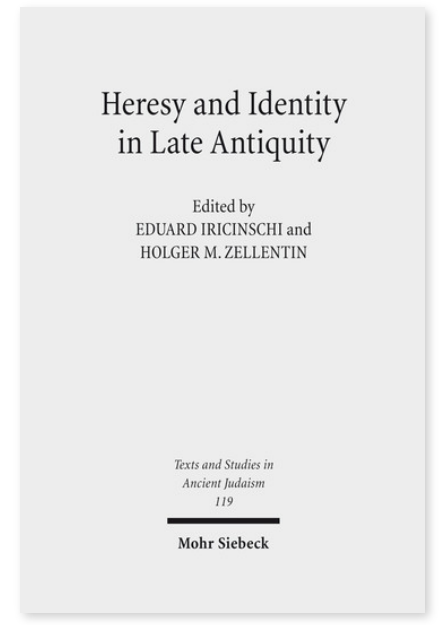

2008. VIII, 407 Seiten. TSAJ 119

ISBN 978-3-16-151452-4

DOI 10.1628/978-3-16-151452-4

eBook PDF 99,00€

ISBN 978-3-16-149122-1

Leinen $99,00 €$
Veröffentlicht auf Englisch.

Die Autoren der Beiträge dieses Bandes untersuchen, wie Diskurse von Häresie und Häretikern es Gruppen in der Spätantike erlauben, ihre eigenen sozio-politischen Grenzen zu definieren und damit sichere Gruppenzugehörigkeiten zu schaffen. Eine weitere Definition von »Häresie« und »Häretikern« als echte oder konstruierte »interne Gegnerschaft « und »interne Gegner « führt zu einem neuen Verständnis von alten Quellen und zu neuen Möglichkeiten des Vergleichs. Die Autoren betrachten das soziale Milieu der Häresiologie und prüfen, wie solche Diskurse dazu dienten, wechselseitige Beziehungen zu regulieren.

Inhaltsübersicht

\section{Content:}

Eduard Iricinschi and Holger Zellentin: Introduction. From Heresy to Heresiology: Recent Trends in Scholarship and the Contribution of This Volume - Karen L. King: Social and Theological Effects of Heresiological Discourse - William E. Arnal: Doxa, Heresy, and Self-Construction. The Pauline Ekklesiai and the Boundaries of Urban Identities - Averil Cameron: The Violence of Orthodoxy - Yannis Papadoyannakis: Defining Orthodoxy in Pseudo-Justin's »Quaestiones et responsiones ad orthodoxos« - Caroline Humfress: Citizens and Heretics: Late Roman Lawyers on Christian Heresy - Richard Lim: The Nomen Manichaeorum and Its Uses in Late Antiquity - Annette Yoshiko Reed: Heresiology and the (Jewish-)Christian Novel: Narrativized Polemics in the Pseudo-Clementine Homilies - Kevin Lee Osterloh: Judea, Rome and the Hellenistic Oikoumenê: Emulation and the Reinvention of Communal Identity - Philippa Townsend: Who Were the First Christians? - John G. Gager: Where Does Luke's Anti-Judaism Come from? - Holger Zellentin: Margin of Error: Bavli Shabbat 116a-b as Polemics, Apology, and Heresiology - Burton L. Visotzky: Goys 'Я'n't Us: Rabbinic Anti-Gentile Polemic in Yerushalmi Berachot 9:1 - Eduard Iricinschi: If You Got It, Flaunt It: Religious Advertising in the Gospel of Philip - Gregg Gardner: Astrology in the Talmud: An Analysis of Bavli Shabbat 156 - Israel Jacob Yuval: The Other in Us: Liturgica, Poetica, Polemica

Eduard Iricinschi Born 1968; MA in Religious Studies from New York University; PhD in the Religions of Late Antiquity from Princeton University; currently visiting research fellow at the Käte Hamburger Kolleg, Ruhr University Bochum.

Holger Michael Zellentin Born 1976; 2007 PhD Princeton University; has taught at Rutgers University, the Graduate Theological Union, Berkeley, and at the University of California, Berkeley; teaches Jewish Studies at the University of Nottingham; 2012 Early Career Fellowship of the Arts and Humanities Research Council (UK).

Jetzt bestellen:

https://mohrsiebeck.com/buch/heresy-and-identity-in-late-antiquity-9783161514524?no_cache=1

order@mohrsiebeck.com

Telefon: +49 (0)7071-923-17

Telefax: +49 (0)7071-51104 